\title{
REGENERASI TUNAS ADVENTIF DARI EKSPLAN DAUN TEMBESU (Fagraea fragrans Roxb.) MELALUI TEKNIK KULTUR JARINGAN
}

\author{
(Regeneration of Adventitious Shoots From Leaf Explant of Tembesu (Fagraea fragrans \\ Roxb.) by tissue culture)
}

\author{
Ratna Uli Damayanti $S^{1}$, Supriyanto ${ }^{2}$, Arum Sekar Wulandari ${ }^{2}$ dan/and \\ Benny Subandy ${ }^{2}$ \\ ${ }^{1}$ Balai Penelitian Teknologi Perbenihan Tanaman Hutan \\ Jl. Pakuan Ciheuleut PO BOX 105 \\ ${ }^{2}$ Departemen Silvikultur, Fakultas Kehutanan IPB \\ J1. Lingkar Kampus IPB, Darmaga Bogor 16680, Jawa Barat, Indonesia \\ ${ }^{3}$ Pusat Perbenihan dan Persemaian Rumpin, Kementrian Kehuanan, Bogor \\ Jl. Prada samlawi no 1, Bogor, Jawa Barat, Indonesia
}

Tanggal diterima: 12 Agustus 2016; Tanggal direvisi: 3 Mei 2017; Tanggal disetujui: 22 Juni 2017

\begin{abstract}
Tembesu (Fagraea fragrans Roxb.) is one of native tree species in peatland forest and has high economical values. Sufficient amount in time of qualified seedlings is needed to support peatland rehabilitation program, and it can be achieved by tissue culture. The objective of the research was to find out the best modification medium of MS based on concentration of nitrogen and BAP for induction and multiplication of adventitious shoot from leaves. The protocol of tissue culture consisted of preparation of plant material, adventitious shoots induction, shoots multiplication, shoots elongation, rooting and seedling acclimatization. The results showed (1) addition of BAP $1.5 \mathrm{ppm}$ on MS medium (80 mmol $N$ ) induced adventitious shoots from leaves; (2) addition of BAP $0.1 \mathrm{ppm}$ on MS medium ( $80 \mathrm{mmol} \mathrm{N}$ ) stimulated the highest multiplication of shoots; (3). clone 2 was the best explant on elongation and rooting stage; (4). clone 4 was the best explant in acclimatization stage.
\end{abstract}

Keywords : Fagraea fragrans, tissue culture, medium, organogenesis

\begin{abstract}
ABSTRAK
Tembesu (Fagraea fragrans Roxb.) merupakan jenis pohon yang mampu tumbuh di hutan rawa gambut dan bernilai ekonomi tinggi. Untuk mendukung program rehabilitasi lahan gambut, maka diperlukan bibit yang berkualitas, jumlah yang cukup dan tepat waktu. Upaya yang diperlukan dalam menyediakan bibit tersebut adalah perbanyakan bibit melalui teknik kultur jaringan. Tujuan penelitian adalah mendapatkan komposisi media tumbuh MS dan zat pengatur tumbuh yang tepat dalam pembentukan dan perbanyakan tunas adventif dari daun tembesu. Metode penelitian terdiri dari persiapan bahan tanaman, induksi tunas adventif, perbanyakan tunas adventif, elongasi, pengakaran dan aklimatisasi. Penelitian menunjukkan bahwa hasil yang terbaik yaitu (1) untuk menginduksi tunas adventif diperlukan media MS (80 mmol N) dengan penambahan BAP 1,5 ppm; (2) untuk perbanyakan tunas adventif diperlukan media MS (60 mmol N) dengan penambahan 0,1 ppm BAP; (3) pada tahap elongasi dan pengakaran lebih baik menggunakan tunas adventif dari klon 2; dan (4) pada tahap aklimatisasi lebih baik menggunakan tunas adventif klon 4.
\end{abstract}

Kata kunci : Fagraea fragrans, kultur jaringan, media, organogenesis

\section{PENDAHULUAN}

Tembesu (Fagraea fragrans Roxb.) termasuk famili Gentianaceae. Tembesu secara alami tumbuh di hutan alam rawa gambut. Sebarannya mulai Indomalaysia sampai ke Birmania (Jonville et al., 2008). Berdasarkan habitat alaminya mampu hidup di kondisi lahan asam. Secara ekologi pohon tembesu termasuk 
jenis pionir yang tumbuh di lahan bekas terbakar dan padang rumput. Kayunya digunakan untuk kayu ukir, konstruksi bangunan. Ekstrak daun dan kulit batang tembesu menghasilkan secoiridoid aglycone yang diberi nama fagraldehyde yang berkhasiat sebagai obat malaria, disentri dan penurun panas (Jonville et al., 2008).

Permintaan kayu tembesu di kota Palembang pada tahun 2011 mencapai $3.120 \mathrm{~m}^{3} /$ tahun (A Sofyan, Lukman, Junaidah, \& Nasrun, 2013). Kesulitan mendapatkan bahan baku kayu tembesu disebabkan eksploitasi berlebih dan kebakaran hutan yang terjadi hampir setiap tahun sehingga potensi tegakan tembesu di alam semakin menurun. Untuk meningkatkan potensi tegakan tembesu, upaya yang dilakukan, yaitu penanaman di lahan hutan alam tidak produktif dan mengembangkan tembesu di areal hutan tanaman. Saat ini, kegiatan penanaman tembesu masih menggunakan bibit asalan (cabutan alami dan benih yang diperoleh bukan hasil pemuliaan). Inisiasi percepatan penyediaan bibit berkualitas melalui teknik vegetatif dari pohon plus sangat diperlukan. Salah satu teknik vegetatif yang dapat menjamin ketersersediaan bibit berkualitas secara terus-menerus yaitu melalui teknik mikropropagasi dari daun.

Teknik mikropropagasi dari material daun merupakan salah satu teknik kultur jaringan yang diharapkan bisa memperbanyak klon-klon dengan produktivitas tegakan yang tinggi. Regenerasi tanaman melalui teknik kultur jaringan tembesu telah dilakukan melalui teknik mikropropagasi daun tembesu (Ardiansyah, 2015). Hal yang perlu dilakukan lebih lanjut yaitu bagaimana diperolehnya komposisi media dan zat pengatur tumbuh yang tepat untuk kultur jaringan dari material daun tembesu Berdasarkan hal tersebut, maka perlu dilakukan penelitian untuk memperoleh bibit berkualitas dalam jumlah yang banyak. Tujuan penelitian adalah mendapatkan media tumbuh dan zat pengatur tumbuh yang tepat dalam pembentukan tunas adventif dari daun tembesu.

\section{METODOLOGI}

\section{A. Lokasi Penelitian}

Penelitian dilakukan di Tissue Culture Laboratory, Rumpin Seed Source and Nursery Center (RSSNC), Bogor. Penelitian dilakukan pada bulan Agustus 2015 sampai dengan Juli 2016.

\section{B. Metode}

\section{Persiapan bahan tanaman}

Eksplan yang digunakan dalam penelitian adalah tunas lateral dengan panjang 1-2 $\mathrm{cm}$ dari bibit tembesu umur sepuluh bulan. Sterilisasi eksplan dilakukan di luar dan di dalam laminar air flow cabinet. Eksplan dicuci dengan deterjen sebanyak $1 \mathrm{~g} / 1$ selama 10 menit, kemudian dibilas dengan air mengalir. Eksplan yang sudah dibilas dipindah dalam larutan fungisida (bahan aktif propineb $70 \%$ ) sebanyak $2 \mathrm{~g} / 1$ ditambah tween 3 tetes dan dikocok dengan shaker selama 60 menit, kemudian dibilas air destilasi hingga bersih. Perendaman selanjutnya dalam larutan bakterisida (bahan aktif streptomisin sulfat 6,41\%) sebanyak $2 \mathrm{~g} / 1$ ditambah tween 3 tetes dan dikocok dengan shaker selama 60 menit, kemudian dibilas air destilasi hingga bersih. Penggunaan tween 20 berfungsi sebagai pelembab permukaan eksplan agar bahan yang akan disterilisasi dapat menyerap dengan baik. Proses sterilisasi lanjutan dikerjakan di dalam laminar air flow cabinet yaitu perendaman larutan hipoklorit 0,5\% ditambahkan satu tetes tween 20 dan dikocok menggunakan shaker selama 10 menit, kemudian dibilas menggunakan air steril sampai bersih. Berikutnya direndam dalam larutan hipoklorit $0,75 \%$ ditambahkan satu tetes tween 20 dan 


\section{Regenerasi Tunas Adventif Dari Eksplan Daun Tembesu (Fagraea fragrans Roxb.) Melalui Teknik Kultur Jaringan}

Ratna Uli Damayanti S, Supriyanto, Arum Sekar Wulandari dan Benny Subandy

dikocok menggunakan shaker selama 15 menit, kemudian dibilas menggunakan air steril sampai bersih. Tahap akhir sterilisasi, eksplan direndam dalam larutan aklohol $70 \%$ selama 1 menit. Eksplan yang telah disteril ditanam dalam media MS (Murashige dan Skoog) dengan jumlah nitrogen $80 \mathrm{ppm}$ ditambah BAP (Benzylaminopurine) 1,5 ppm (Ardiansyah, Supriyanto, Wulandari, Subandy, \& Fitriani, 2014). Eksplan aseptik diambil dari bagian daun yang telah terbuka pada ruas pertama dan kedua untuk digunakan pada penelitian ini.

\section{Induksi dan perbanyakan tunas adventif}

Induksi pembentukan tunas dari daun bertujuan untuk mengetahui apakah tunas dapat terbentuk dari daun tembesu. Induksi pembentukan tunas dari daun dilakukan dengan tiga kali percobaan. Tahap percobaan pertama, menguji media dengan konsentrasi nitrogen sebanyak 60 mmol $\left(\mathrm{NO}_{3}{ }^{-}: \mathrm{NH}_{4}{ }^{+}=2: 1,(\mathrm{v} / \mathrm{v})\right)$ ditambah dengan zat pengatur tumbuh BAP berbagai konsentrasi. Penelitian menggunakan Rancangan Acak Lengkap (RAL) dengan perlakuan konsentrasi zat pengatur tumbuh BAP yaitu konsentrasi 1 ; 1,5; dan 2 ppm. Setiap perlakuan diulang tiga kali dan setiap unit percobaan terdiri atas sepuluh tanaman. Total unit yang diamati adalah sembilan puluh tanaman untuk percobaan pertama. Tahap percobaan kedua, menguji media dengan konsentrasi nitrogen $80 \mathrm{ppm}$ $\left(\mathrm{NO}_{3}{ }^{-}: \mathrm{NH}_{4}{ }^{+}=3: 1,(\mathrm{v} / \mathrm{v})\right)$ ditambah BAP berbagai konsentrasi. Rancangan yang digunakan adalah RAL dengan perlakuan konsentrasi nitrogen $80 \mathrm{ppm}$ yang ditambah dosis zat pengatur tumbuh BAP (konsentrasi 1; 1,5; dan 2 ppm). Setiap perlakuan diulang tiga kali dan setiap unit percobaan terdiri atas sepuluh tanaman. Total unit yang diamati adalah sembilan puluh tanaman untuk percobaan kedua.
Dari hasil percobaan pertama dan kedua yang terbaik, selanjutnya dilakukan tahap percobaan ketiga, yaitu pengujian induksi tunas adventif dari daun tembesu. Rancangan yang digunakan adalah RAL dengan perlakuan konsentarsi nitrogen 60 mmol $\left(\mathrm{NO}_{3}{ }^{-}: \mathrm{NH}_{4}{ }^{+}=2: 1,(\mathrm{v}: \mathrm{v})\right) ; 70$ mmol $\left(\mathrm{NO}_{3}{ }^{-}: \mathrm{NH}_{4}{ }^{+}=2,5: 1,(\mathrm{v}: \mathrm{v})\right) ; 80$ mmol $\left(\mathrm{NO}_{3}{ }^{-}: \mathrm{NH}_{4}{ }^{+}=3: 1,(\mathrm{v}: \mathrm{v})\right) ; 90$ mmol $\left(\mathrm{NO}_{3}^{-}: \mathrm{NH}_{4}^{+}=3,5: 1,(\mathrm{v}: \mathrm{v})\right)$ dan

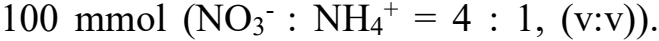
Setiap perlakuan terdiri atas tiga ulangan dan setiap unit percobaan terdiri atas sepuluh tanaman. Total unit yang diamati adalah 150 tanaman untuk percobaan ketiga.

Penempatan eksplan di dalam media kultur jaringan dilakukan dengan bagian bawah daun menyentuh media. Botol kultur yang telah terisi eksplan ditutup dan diletakkan di ruang kultur pada suhu $(24 \pm 1)^{\circ} \mathrm{C}$ dengan cahaya lampu TL 5 Watt. Pengamatan dilakukan setelah 4 minggu. Parameter yang diamati adalah persentase tumbuh, persentase tunas adventif, jumlah tunas adventif per eksplan, waktu muncul tunas adventif, dan jumlah tunas aksiler per eksplan.

Multiplikasi dilakukan dengan cara memindahkan seluruh bagian (daun dan tunas) kedalam media dengan jumlah nitrogen sebanyak $60 \mathrm{mmol}\left(\mathrm{NO}_{3}{ }^{-}: \mathrm{NH}_{4}{ }^{+}\right.$ $=3: 1,(\mathrm{v} / \mathrm{v}))$ ditambah zat pengatur tumbuh BAP sebanyak $0,1 \mathrm{ppm}$. Hal ini dimaksudkan untuk menghilangkan kebutuhan eksplan terhadap zat pengatur tumbuh. Pemindahan selanjutnya ke media pemanjangan akan dilakukan tanpa penggunaan zat pengatur tumbuh. Eksplan yang diperbanyak adalah eksplan yang berasal dari tunas adventif. Karena eksplan yang didapat jumlahnya tidak memenuhi syarat untuk diujicobakan, maka tidak dilakukan uji secara statistik tetapi dilakukan pengamatan secara deskriptif. 


\section{Elongasi, pengakaran dan aklimati- sasi tunas adventif}

Tunas yang dihasilkan pada tahap multiplikasi kemudian ditanam pada media $1 / 2$ MS ditambah arang sebanyak 1 g/l. Tahapan elongasi dan pengakaran dijadikan satu, karena eksplan tembesu dapat berakar tanpa diinduksi menggunakan zat pengatur tumbuh auksin (Ardiansyah, 2015). Tahap elongasi dan pengakaran dilakukan untuk melihat pertumbuhan eksplan asal aksiler dan adventif. Rancangan percobaan yang digunakan adalah RAL dengan perlakuan asal tunas adventif dan aksiler. Setiap perlakuan diulang tiga kali dan setiap ulangan berisi sepuluh tanaman. Total unit yang diamati adalah 150 tanaman. Eksplan diamati pada minggu ke-4. Parameter yang diamati adalah persentase tumbuh, panjang tunas, jumlah akar, dan panjang akar.

Planlet yang telah berakar dari setiap perlakuan diaklimatisasi menggunakan media campuran tanah, pasir dan arang sekam dengan perbandingan 1:1:0,25, (v/v/v). Media tersebut disterilisasi menggunakan autoklaf pada suhu $121-126^{\circ} \mathrm{C}$ dan tekanan 1,5 atm selama 20-40 menit. Planlet yang dipindahkan minimal sudah memiliki akar. Planlet terpilih kemudian disimpan pada suhu $26-28^{\circ} \mathrm{C}$ selama 2-3 hari untuk menyesuaikan kondisi dari ruang ber-AC. Planlet dikeluarkan dari botol kultur, akarnya dicuci sampai media yang menempel hilang (menghindari kontaminasi fungi). Planlet yang telah bersih direndam dalam larutan bakterisida dan fungisida masing-masing sebanyak $1 \mathrm{~g} / \mathrm{l}$ selama 15 menit, kemudian ditanam dalam media aklimatisasi. Wadah aklimatisasi yang digunakan adalah wadah plastik berdiameter $8 \mathrm{~cm}$, dalam satu wadah ditanam satu eksplan. Wadah aklimatisasi yang telah terisi ditutup rapat menggunakan plastik untuk menghindari terjadinya penguapan berlebih. Wadah berisi planlet ditempatkan di dalam box plastik dan disimpan dalam tempat yang teduh.

Planlet yang ditanam adalah tunas adventif dan tunas aksiler. Tahap aklimatisasi dilakukan untuk mengetahui kemampuan adaptasi dan pertumbuhan planlet tembesu. Rancangan yang digunakan adalah RAL dengan perlakuan asal tunas. Setiap perlakuan terdiri atas tiga ulangan dan setiap perlakuan berisi sepuluh tanaman. Total unit yang diamati adalah 150 tanaman. Eksplan diamati setelah 4 minggu, dengan parameter yang diamati adalah persentase tumbuh, jumlah daun baru, dan tinggi bibit.

\section{Analisis Data}

Data yang diambil kemudian dianalisis menggunakan sofware Microsoft Excel, SAS Version 9.1, dan Minitab Version 16. Untuk menentukan perbedaan antar perlakuan dilakukan uji jarak berganda Duncan.

\section{HASIL DAN PEMBAHASAN}

\section{A. Hasil \\ 1. Tahap induksi tunas dari daun}

Tiga langkah yang ditempuh untuk menghasilkan tunas adventif dari daun tembesu yaitu (1) modifikasi konsentrasi zat pengatur tumbuh BAP untuk mendapatkan konsentrasi BAP terbaik, (2) modifikasi konsentrasi nitrogen, dan (3) mengkombinasikan konsentrasi BAP dan nitrogen yang terbaik untuk menginduksi tunas adventif. Berdasarkan hasil sidik ragam pada percobaan pertama, bahwa konsentrasi BAP berpengaruh nyata terhadap persentase tunas adventif, jumlah tunas adventif per eksplan, waktu muncul tunas adventif dan jumlah tunas aksiler per eksplan, namun terhadap persentase tumbuh eksplan tidak berpengaruh nyata. Hasil uji Duncan (Tabel 1) menunjukkan bahwa konsentrasi BAP 1,5 ppm mampu menghasilkan persentase tunas adventif, 


\section{Regenerasi Tunas Adventif Dari Eksplan Daun Tembesu (Fagraea fragrans Roxb.) Melalui Teknik Kultur Jaringan}

Ratna Uli Damayanti S, Supriyanto, Arum Sekar Wulandari dan Benny Subandy

jumlah tunas adventif dan waktu muncul tunas adventif yang berbeda nyata dengan konsentasi BAP 1 dan 2 ppm, kecuali konsentrasi BAP 1 ppm menghasilkan jumlah tunas aksiler per eksplan yang tertinggi dan berbeda nyata dengan konsentrasi lainnya. Hasil analisis uji Duncan disajikan pada Tabel 1.

Tabel 1 menunjukkan bahwa konsentrasi BAP 1 dan 2 ppm tidak dapat menginduksi tunas adventif, tetapi tunas yang muncul adalah tunas aksiler. Konsentrasi BAP 1 dan 1,5 ppm samasama memiliki persentase tumbuh yang hampir sama, akan tetapi memiliki perbedaan terhadap kemampuan memunculkan tunas adventif dan tunas aksiler. Konsentrasi BAP sebanyak 1 ppm mampu menghasilkan tunas aksiler lebih banyak, tetapi tidak dapat menginduksi tunas adventif, kecuali konsentrasi 1,5 ppm menginduksi tunas adventif dari daun. Semakin tinggi dosis BAP yang digunakan pada media nitrogen $60 \mathrm{ppm}$, maka jumlah tunas aksiler yang muncul akan semakin sedikit. Konsentrasi BAP 1,5 ppm memiliki persentase tumbuh yang tidak berbeda nyata dengan BAP 1 dan 2 ppm, akan tetapi konsentrasi tersebut merupakan konsentrasi yang dapat menginduksi tunas adventif. Banyaknya tunas adventif yang dihasilkan adalah $13 \%$ dari eksplan yang tumbuh, jumlah tunas yang dihasilkan adalah 1 tunas per eksplan yang muncul pada minggu ke-4 setelah ditanam. Dengan demikian, untuk menginduksi tunas adventif pada media dengan konsentrasi nitrogen 60 mmol sebaiknya dilakukan penambahan BAP sebanyak 1,5 ppm.

Selain media dengan konsentrasi nitrogen $60 \mathrm{mmol}$, konsentrasi nitrogen 80 mmol juga diujicobakan pada media dengan hasil bahwa dosis BAP berpengaruh signifikan terhadap persentase tumbuh eksplan, jumlah tunas adventif per eksplan dan jumlah tunas aksiler per eksplan, namun terhadap waktu muncul tunas adventif tidak berpengaruh nyata.

Hasil uji lanjut menunjukkan bahwa konsentrasi BAP 1 dan 1,5 ppm memiliki persentase tumbuh yang tidak berbeda nyata, tetapi berbeda nyata dengan konsentrasi 2 ppm (Tabel 2). Penambahan BAP sebanyak 2 ppm dapat menghambat pertumbuhan eksplan, jumlah tunas adventif dan jumlah tunas aksiler. Konsentrasi 1; 1,5; dan 2 ppm terbukti dapat memunculkan tunas adventif dari daun. Pada percobaan ini terlihat adanya peningkatan persentase tunas adventif dan jumlah tunas adventif dibandingkan percobaan pertama. Pada percobaan pertama konsentrasi BAP 1 dan 2 ppm tidak dapat menginduksi tunas adventif, sedangkan pada percobaan kedua tunas adventif muncul dari daun tembesu. Jumlah tunas adventif yang dihasilkan dari daun sebanyak satu tunas per eksplan untuk konsentrasi 1 dan 2 ppm, sedangkan konsentrasi 1,5 ppm menghasilkan tiga tunas per eksplan. Hal ini membuktikan bahwa penambahan konsentrasi nitrogen dari $60 \mathrm{mmol}$ menjadi $80 \mathrm{mmol}$ dalam media mempengaruhi kemunculan tunas adventif.

Rata-rata persentase tunas yang didapatkan dari konsentrasi BAP sebanyak 1,5 ppm merupakan persentase tunas adventif tertinggi (38\%) dibandingkan dua konsentrasi lainnya. Konsentrasi BAP 1,5 ppm merupakan konsentrasi dengan persentase tumbuh eksplan tertinggi (93\%) dan jumlah tunas adventif terbanyak (tiga tunas per eksplan). Dengan demikian kosentrasi BAP sebanyak 1,5 ppm pada percobaan kedua merupakan konsentrasi yang optimal untuk memunculkan tunas adventif dari daun.

Pada media yang diberi nitrogen 80 mmol yang ditambahkan dosis BAP 1 dan 1,5 ppm menghasilkan jumlah tunas aksiler yang lebih tinggi dan berbeda nyata daripada konsentrasi BAP 2 ppm. Sama halnya yang terjadi pada percobaan 
pertama, penambahan BAP dalam media menurunkan jumlah tunas aksiler. Percobaan pertama, konsentrasi maksi-mum untuk menginduksi tunas aksiler adalah 1 ppm, sedangkan percobaan kedua konsentrasi maksimum adalah 1,5 ppm.

Berdasarkan percobaan pertama dan kedua dapat disimpulkan bahwa konsentrasi BAP sebanyak 1,5 ppm yang ditambahkan dalam media merupakan konsentrasi terbaik untuk menginduksi tunas adventif. Peningkatan konsentrasi nitrogen dari $60 \mathrm{mmol}$ menjadi $80 \mathrm{mmol}$ dalam media berpengaruh terhadap respon pertumbuhan tunas adventif dan tunas aksiler yang dihasilkan.

Tabel (Table) 1. Pengaruh zat pengatur tumbuh BAP dalam media dengan konsentrasi nitrogen $60 \mathrm{mmol}$ terhadap pertumbuhan tunas adventif tembesu (The effects of plant growth regulator BAP on the medium $60 \mathrm{mmol}$ of nitrogen concentration to the adventitious shoots of tembesu)

\begin{tabular}{|c|c|c|c|c|c|}
\hline $\begin{array}{c}\text { Konsentrasi } \\
\text { BAP } \\
(\text { Concentration } \\
\text { of BAP })(\mathrm{ppm})\end{array}$ & $\begin{array}{c}\text { Persentase } \\
\text { tumbuh } \\
\text { (Survival) } \\
(\%)\end{array}$ & $\begin{array}{c}\text { Persentase } \\
\text { tunas adventif } \\
\text { (The } \\
\text { adventitious } \\
\text { shoot) }(\%)\end{array}$ & $\begin{array}{l}\text { Jumlah tunas } \\
\text { adventif per } \\
\text { eksplan } \\
\text { (Number of } \\
\text { adventitious } \\
\text { per explant) } \\
\text { (Tunas) } \\
\text { (Shoot) }\end{array}$ & $\begin{array}{l}\text { Waktu muncul } \\
\text { tunas adventif } \\
\text { (Time of } \\
\text { adventitious } \\
\text { shoot) } \\
\text { (Minggu ke-) } \\
\text { (Week to) }\end{array}$ & $\begin{array}{l}\text { Jumlah tunas } \\
\text { aksiler per } \\
\text { eksplan } \\
\text { (Number of } \\
\text { axiler shoot } \\
\text { per explant) } \\
\text { (Tunas) } \\
\text { (Shoot) }\end{array}$ \\
\hline 1,0 & $73 \mathrm{a}$ & $0 \mathrm{~b}$ & $0 \mathrm{~b}$ & $0 \mathrm{~b}$ & $7 \mathrm{a}$ \\
\hline 1,5 & $70 \mathrm{a}$ & $13 \mathrm{a}$ & $1 \mathrm{a}$ & $4 \mathrm{a}$ & $4 \mathrm{~b}$ \\
\hline 2,0 & $80 \mathrm{a}$ & $0 \mathrm{~b}$ & $0 \mathrm{~b}$ & $0 \mathrm{~b}$ & $3 \mathrm{~b}$ \\
\hline
\end{tabular}

Keterangan (Remaks): Data sudah ditranformasi menggunakan metode arcsin $\sqrt{\%}$ (Data were transformed using arcsin $\sqrt{ } \%$ method); Angka rerata yang diikuti oleh huruf yang sama pada kolom yang sama menunjukkan tidak berbeda nyata berdasarkan uji wilayah berganda duncan pada taraf 5\% (Mean followed by the same letter in the same column are not significantly different based on duncan multiple range test (DMRT) at $p=0.05$ )

Tabel (Table) 2. Pengaruh zat pengatur tumbuh BAP dalam media dengan jumlah nitrogen $80 \mathrm{mmol}$ terhadap pertumbuhan tunas adventif tembesu (The effects of plant growth regulator BAP on medium $80 \mathrm{mmol}$ of nitrogen concentration to adventitious shoots of tembesu)

\begin{tabular}{|c|c|c|c|c|c|}
\hline $\begin{array}{c}\text { Konsentrasi } \\
\text { BAP } \\
(\text { Concentration } \\
\text { of BAP) (ppm) }\end{array}$ & $\begin{array}{c}\text { Persentase } \\
\text { tumbuh } \\
\text { (Survival) } \\
(\%)\end{array}$ & $\begin{array}{c}\text { Persentase } \\
\text { tunas } \\
\text { adventif (The } \\
\text { adventitious } \\
\text { shoot) }(\%)\end{array}$ & $\begin{array}{l}\text { Jumlah tunas } \\
\text { adventif per } \\
\text { eksplan } \\
\text { (Number of } \\
\text { adventitious per } \\
\text { explant) (Tunas) } \\
\text { (Shoot) }\end{array}$ & $\begin{array}{l}\text { Waktu muncul } \\
\text { tunas adventif } \\
\text { (Time of } \\
\text { adventitious } \\
\text { shoot) (Minggu } \\
\text { ke-) (Week to) }\end{array}$ & $\begin{array}{l}\text { Jumlah tunas } \\
\text { aksiler per } \\
\text { eksplan (Number } \\
\text { of axiler shoot } \\
\text { per explant) } \\
\text { (Tunas) } \\
\text { (Shoot) }\end{array}$ \\
\hline 1,0 & $90 \mathrm{a}$ & $23 \mathrm{~b}$ & $1 \mathrm{~b}$ & 4 & $10 \mathrm{a}$ \\
\hline 1,5 & $93 \mathrm{a}$ & $40 \mathrm{a}$ & $3 \mathrm{a}$ & $4 \mathrm{a}$ & $11 \mathrm{a}$ \\
\hline 2,0 & $57 \mathrm{~b}$ & $20 \mathrm{~b}$ & $1 \mathrm{~b}$ & $3 \mathrm{a}$ & $7 \mathrm{~b}$ \\
\hline
\end{tabular}

Keterangan (Remaks) : Data sudah ditranformasi menggunakan metode arcsin $\sqrt{\%}$ (Data were transformed using $\arcsin \sqrt{ } \%$ method); Angka rerata yang diikuti oleh huruf yang sama pada kolom yang sama menunjukkan tidak berbeda nyata berdasarkan uji wilayah berganda duncan pada taraf 5\% (Mean followed by the same letter in the same column are not significantly different based on duncan multiple range test (DMRT) at $p=0.05$ ) 
Selanjutnya, dilakukan percobaan ketiga yang ditujukan untuk mendapatkan modifikasi konsentrasi nitrogen $(60,70$, 80, 90 dan $100 \mathrm{mmol}$ ) dalam media MS. Kelima konsentrasi nitrogen dalam media ditambahkan BAP sebanyak 1,5 ppm. Hasil sidik ragam menunjukkan bahwa konsentrasi nitrogen berpengaruh nyata terhadap persentase tumbuh, persentase tunas adventif, jumlah tunas adventif per eksplan dan jumlah tunas aksiler per eksplan. Untuk melihat konsentrasi nitrogen terbaik, maka dilakukan uji lanjut Duncan terhadap respon pertumbuhan disajikan pada Tabel 3.

Persentase tumbuh eksplan pada konsentrasi nitrogen dalam media 60,70 dan $80 \mathrm{mmol}$ merupakan persentase tertinggi (100\%), dan ketika konsentrasi nitrogen ditingkatkan menjadi 90 dan 100 mmol terjadi penurunan persentase tumbuh eksplan. Penurunan juga terjadi pada persentase tunas adventif dan tidak berbeda nyata pada ketiga konsentrasi nitrogen (60, 70 dan $80 \mathrm{mmol})$. Media dengan konsentrasi nitrogen sebanyak 60 dan $70 \mathrm{mmol}$ menginduksi tunas adventif dengan nilai persentase tunas adventif yang sama, tetapi jumlah tunas yang dihasilkan per eksplan berbeda.

Konsentrasi nitrogen $70 \mathrm{mmol}$ dalam media mampu menghasilkan tunas adventif sebanyak tujuh tunas per eksplan dan merupakan jumlah tunas adventif terbanyak yang didapatkan dalam penelitian ini. Konsentrasi nitrogen dalam media 70 dan 80 mmol tidak berbeda nyata terhadap induksi tunas adventif dengan jumlah total tunas yang hampir sama. Akan tetapi, media dengan konsentrasi nitrogen $80 \mathrm{mmol}$ menghasilkan persentase tunas adventif yang lebih besar 30\%, sehingga dimungkinkan untuk menghasilkan tunas adventif lebih banyak. Penggunaan media dengan konsentrasi nitrogen $80 \mathrm{mmol}$ merupakan konsentrasi terbaik untuk menginduksi tunas adventif.
Kelima konsentrasi nitrogen menghasilkan jumlah tunas aksiler yang berbeda. Jumlah tunas aksiler terbaik diinduksi menggunakan konsentrasi nitrogen 70 dan 80 ppm, tetapi tidak berbeda nyata dengan konsentrasi nitrogen 60 mmol. Ketika penambahan konsentrasi dilakukan menjadi 90 dan 100 ppm, maka terjadi penurunan jumlah tunas aksiler per eksplan. Hal ini membuktikan bahwa kadar nitrogen dalam media khususnya nitrat dapat merugikan bagi tanaman. Tidak hanya jumlah tunas aksiler yang turun nilainya, persentase tumbuh eksplan, persentase tunas adventif juga mengalami penurunan pada konsentrasi nitrogen 90 dan $100 \mathrm{mmol}$.

Proses induksi tunas adventif dimulai dengan adanya bentuk titik berwarna putih hingga hijau keputihan pada daun. Lokasi titik tersebut terdapat di tengah, pangkal, tepi atau di urat daun. Tahap awal pembentukan tunas adventif terjadi pada minggu kedua setelah tanam. Sel meristematik tunggal membelah dengan cepat menghasilkan sel globular seperti titik berwarna putih (Gambar 1A) atau titik seperti butiran yang menempel dan kompak.

Sel yang terorganisir di bawah jaringan epidermis pada bagian daun tembesu yang membengkak membentuk suatu jaringan dasar disebut sel meristematik (Gambar 1B). Hal ini sejalan dengan penelitian Ardiansyah ,(2015) bahwa sel yang membengkak di bawah jaringan epiderimis pada daun adalah sel meristematik. Pengamatan pada minggu berikutnya, bentuk awal seperti titik berubah menjadi bulatan (membengkak, butirannya tidak dapat dilihat lagi) salah satu sisinya agak memanjang yang kemudian akan membentuk primodium pucuk (Gambar 1C). Seminggu kemudian bentuk tersebut berubah, bagian pada ujungnya memipih, terbuka ke samping dan berkembang menjadi daun utuh. Perubahan yang terjadi dari mulai munculnya bakal tunas 
adventif (Gambar 1A) menjadi tunas utuh (Gambar 1D) diperlukan waktu selama 46 minggu.

Pada proses pembentukan tunas adventif dalam penelitian ini adalah organogenesis spontan, proses pembentukan pucuknya terjadi secara langsung. Tahapan pembentukan tunas yang terjadi berbeda dengan tahapan embriogenesis (globular, heart shape, torpedo dan kecambah). Tahapan heart shape dan torpedo tidak terjadi, sel globular langsung membentuk bakal tunas.

Perbanyakan tunas adventif dari daun dilakukan dengan cara memindahkan tunas adventif yang masih tumbuh di daun dipindah ke dalam media dengan konsentrasi nitrogen $60 \mathrm{mmol}$ dengan perbandingan $\mathrm{NO}_{3}{ }^{-}: \mathrm{NH}_{4}{ }^{+}=3: 1$ (g/g) ditambah BAP 0,1 ppm. Penambahan BAP dimaksudkan untuk mengurangi pengaruhnya secara bertahap. Pemindahan eksplan ke media elongasi dilakukan tanpa menggunakan ZPT BAP, sehingga diharapkan tunas akan tumbuh tanpa tergantung pada penambahan BAP.

Jumlah eksplan tunas adventif yang masih utuh dengan daunnya sebanyak empat eksplan. Hasil multi-plikasi tunas adventif dapat dilihat pada Gambar 1.

Tabel (Table) 3. Pengaruh perlakuan jumlah nitrogen dalam media terhadap pertumbuhan tunas adventif tembesu (The effect of nitrogen concentration on medium to the growth of adventitious shoots of tembesu)

\begin{tabular}{cccccc}
\hline $\begin{array}{c}\text { Konsentrasi } \\
\text { nitrogen } \\
\text { Concentration } \\
\text { of nitrogen) } \\
\text { (ppm) }\end{array}$ & $\begin{array}{c}\text { Persentase } \\
\text { tumbuh } \\
\text { Survival) } \\
(\%)\end{array}$ & $\begin{array}{c}\text { Persentase } \\
\text { tunas adventif } \\
\text { (The } \\
\text { adventitious } \\
\text { shoot) }(\%)\end{array}$ & $\begin{array}{c}\text { Jumlah tunas } \\
\text { adventif per } \\
\text { eksplan (Number } \\
\text { of adventitious } \\
\text { per explant) } \\
\text { (Tunas) } \\
\text { (Shoot) }\end{array}$ & $\begin{array}{c}\text { waktu muncul } \\
\text { tunas adventif } \\
\text { (Time of } \\
\text { adventitious } \\
\text { shoot) } \\
\text { (Minggu ke-) } \\
\text { (Week to) }\end{array}$ & $\begin{array}{c}\text { Jumlah tunas } \\
\text { aksiler per } \\
\text { eksplan } \\
\text { (Number of } \\
\text { axiler shoot } \\
\text { per explant) } \\
\text { (Tunas) } \\
\text { (Shoot) }\end{array}$ \\
\hline 60 & $100 \mathrm{a}$ & $23 \mathrm{a}$ & $4 \mathrm{~b}$ & $4 \mathrm{a}$ & $8 \mathrm{ab}$ \\
70 & $100 \mathrm{a}$ & $23 \mathrm{a}$ & $7 \mathrm{a}$ & $4 \mathrm{a}$ & $9 \mathrm{a}$ \\
80 & $100 \mathrm{a}$ & $30 \mathrm{a}$ & $5 \mathrm{a}$ & $3 \mathrm{a}$ & $9 \mathrm{a}$ \\
90 & $80 \mathrm{~b}$ & $17 \mathrm{a}$ & $6 \mathrm{a}$ & $2 \mathrm{a}$ & $5 \mathrm{~b}$ \\
100 & $63 \mathrm{~b}$ & $13 \mathrm{a}$ & $4 \mathrm{~b}$ & $4 \mathrm{a}$ & $5 \mathrm{~b}$ \\
\hline
\end{tabular}

Keterangan (Remaks): Data sudah ditranformasi menggunakan metode arcsin $\sqrt{\%}$ (Data were transformed using $\arcsin 1 \%$ method); Angka rerata yang diikuti oleh huruf yang sama pada kolom yang sama menunjukkan tidak berbeda nyata berdasarkan uji wilayah berganda duncan pada taraf 5\%. (Mean followed by the same letter in the same column are not significantly different based on duncan multiple range test (DMRT) at $p=0.05$ ) 

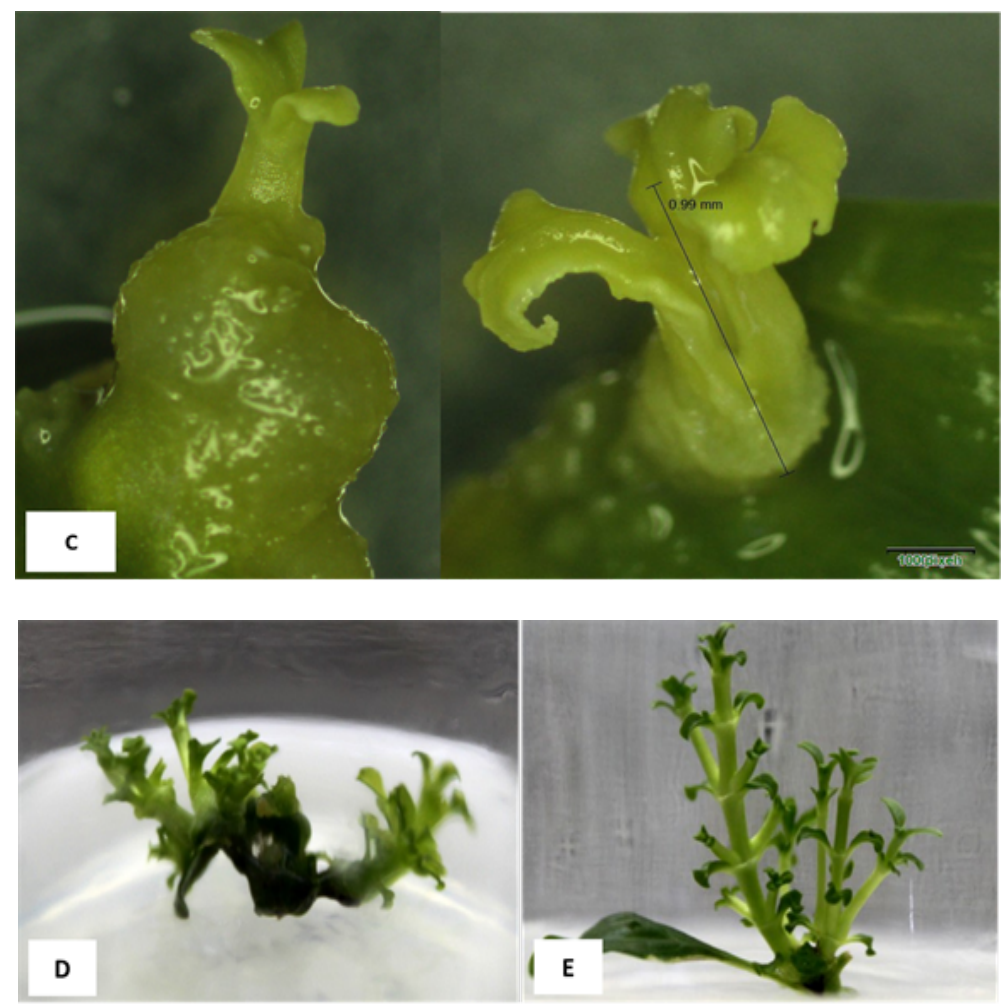

Gambar (Figure) 1. Tahap proses pembentukan tunas adventif pada eksplan tembesu: (A) tahap awal pembentukan tunas adventif, (B) sel meristem di bawah jaringan epidermis daun, (C) primodium pucuk tunas adventif, (D) tunas adventif, (E) tunas aksiler. (The stage of tembesu adventitious shoot formation. (A) early stage of adventitious shoot formation, (B) elongation and bud formation on adventitious shoot formation, $(C)$ the differentiated primary leaves of tembesu adventitious shoot formation), (D) adventitious shoot, (E) axillary shoot.

\section{Multiplikasi tunas dari daun}

Tahap multiplikasi merupakan tahap perbanyakan, berbeda dengan tahap- tahap induksi dimana pada tahap tersebut terjadi proses pembentukan tunas dari ada menjadi tidak ada. Perbanyakan yang dilakukan adalah perbanyakan tunas adventif, sedangkan perbanyakan tunas aksiler telah dilakukan oleh (Ardiansyah, 2015). Banyaknya tunas aksiler yang dihasilkan mencapai sebelas tunas per eksplan. Perbanyakan tunas dari daun dilakukan dengan dua cara. Pertama, memotong tunas kemudian ditanam dalam media, hasil yang didapatkan adalah tunasnya tidak banyak tumbuh bahkan banyak yang mengalami kematian. Kemudian beberapa tunas adventif yang belum dipindah (masih tumbuh di daun) dipindah ke dalam media dengan konsentrasi nitrogen $60 \mathrm{mmol}$ dengan perbandingan $\mathrm{NO}_{3}^{-}: \mathrm{NH}_{4}^{+}=3: 1 \quad(\mathrm{v}: \mathrm{v})$ ditambah BAP 0,1 ppm. Hal ini dimaksudkan untuk mengurangi pengaruh BAP secara bertahap. Pemindahan eksplan ke media elongasi dilakukan tanpa menggunakan ZPT BAP. Jumlah eksplan tunas adventif yang masih utuh dengan daunnya sebanyak empat eksplan. Hasil multiplikasi tunas adventif terlihat pada Gambar 2.

Pada Gambar 2, pertumbuhan jumlah tunas adventif menghasilkan jumlah 
tunas yang tidak berbeda. Jumlah tunas yang dihitung pada minggu ke-10 menghasilkan tunas sebanyak 25-35 tunas per eksplan. Dalam hal ini, BAP sebanyak $0,1 \mathrm{ppm}$ mendorong terbentuknya tunas dari sel meristematik yang terbentuk dalam jaringan eksplan daun. Sel meristematik tersebut terbentuk pada saat induksi tunas adventif. Sel-sel meristematik hanya memerlukan sedikit zat pengatur tumbuh untuk mendorong pembentukan tunas. Tunas adventif yang berhasil diperbanyak berasal dari empat tunas adventif dari daun yang berbeda, selanjutnya keempat tunas adventif tersebut dinamakan klon (1, 2, 3 dan 4). Keempat klon tersebut diperbanyak dan menghasilkan tunas baru, kemudian ditumbuhkan dalam media elongasi untuk dipersiapkan ke tahap aklimatisasi.

\section{Elongasi, pengakaran dan aklimati- sasi}

Hasil analisis sidik ragam menunjukkan bahwa respon pertumbuhan eksplan tunas adventif dipengaruhi oleh asal tunas. Respon pertumbuhan yang menunjukkan adanya keragaman, dilanjutkan dengan uji lanjut. Hasil uji lanjut panjang tunas, persentase berakar dan jumlah akar berbeda nyata pada semua perlakuan.

Dari Tabel 4, dapat disimpulkan bahwa perlakuan terbaik pada tahap elongasi adalah tunas aksiler dengan penambahan panjang tunas sebesar 7.5 mm. Perlakuan terbaik untuk tahap pengakaran berdasarkan persentase barakar dan jumlah akar adalah tunas adventif klon dua (D2). Klon tersebut memiliki kemampuan untuk memunculkan akar lebih banyak.

\section{B. Pembahasan}

Tunas adventif adalah tunas yang muncul bukan dari ujung batang dan ketiak daun (jaringan meristem), melainkan dari bagian tubuh tumbuhan lainnya seperti pada daun, batang, kotiledon, dan akar. Ada empat faktor yang mempengaruh terbentuknya tunas adventif dari daun ; (1) cara menanam (memotong daunnya atau menempatkan dalam media), (2) umur daun, (3) posisi mata tunas dari daun dan (4) rasio antara sitokinin dan auksin.

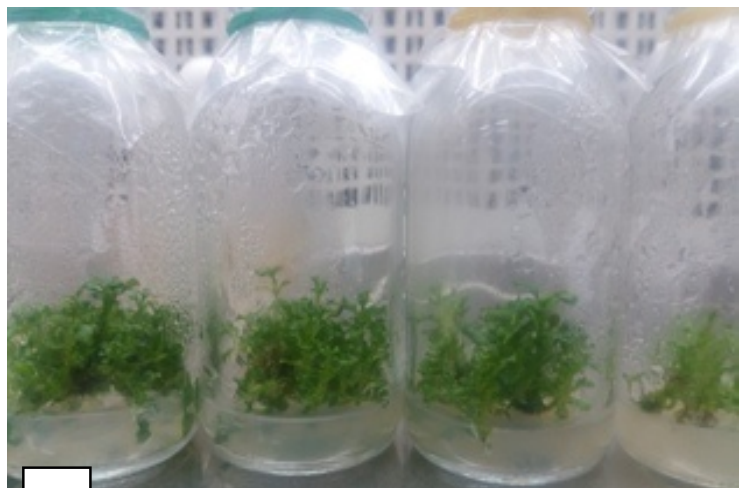

A

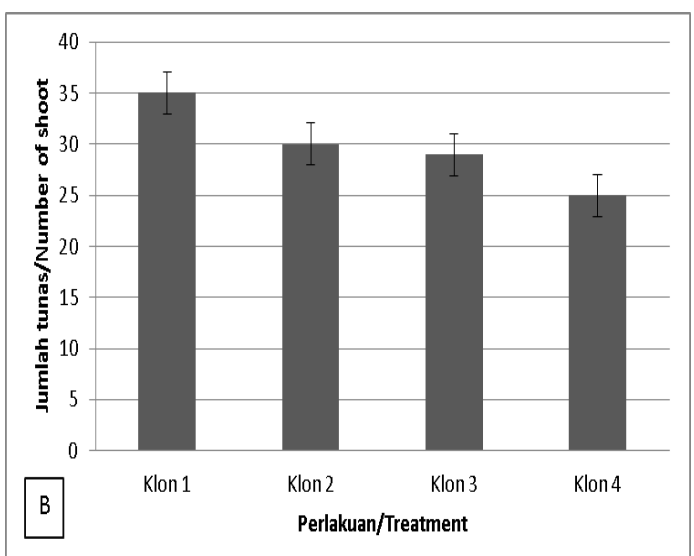

Gambar (Figure) 2. (A) Eksplan tunas adventif tembesu hasil multiplikasi (B) Jumlah tunas adventif tembesu $[(A)$ The explants of tembesu adventitious shoot from multiplication stage. (B) the number of adventitious shoots of tembesu] 
Tabel (Table) 4. Pengaruh asal tunas terhadap respon pertumbuhan eksplan pada tahap elongasi dan pengakaran, serta pertumbuhan bibit pada tahap aklimatisasi (The effect of shoot source to the growth respon on the elongation and rooting stage, and seedling growth on aclimatization)

\begin{tabular}{|c|c|c|c|c|c|c|c|}
\hline \multirow[b]{2}{*}{$\begin{array}{c}\text { Perlakuan } \\
\text { (Treatments) }\end{array}$} & \multicolumn{4}{|c|}{$\begin{array}{l}\text { Elongasi dan pengakaran } \\
\text { (Elongation and rooting) }\end{array}$} & \multicolumn{3}{|c|}{$\begin{array}{c}\text { Aklimatisasi } \\
\text { (Aclimatization) }\end{array}$} \\
\hline & $\begin{array}{c}\text { Persentase } \\
\text { tumbuh } \\
\text { (Survival) } \\
(\%)\end{array}$ & $\begin{array}{l}\text { Penambahan } \\
\text { panjang tunas } \\
\text { (Shoot length } \\
\text { growth) } \\
\text { (mm) }\end{array}$ & $\begin{array}{c}\text { Persentase } \\
\text { berakar } \\
(\text { Rooting } \\
\text { percentage) } \\
(\%)\end{array}$ & $\begin{array}{c}\text { Jumlah akar } \\
\text { (Number of } \\
\text { root) (Tunas) } \\
\text { (Shoot) }\end{array}$ & $\begin{array}{c}\text { Persentase } \\
\text { tumbuh } \\
\text { (Growth } \\
\text { percentage) } \\
(\%)\end{array}$ & $\begin{array}{l}\text { Jumlah } \\
\text { daun baru } \\
\text { (Number of } \\
\text { leaves) } \\
\text { (Tunas) } \\
\text { (Shoot) }\end{array}$ & $\begin{array}{l}\text { Tinggi } \\
\text { bibit } \\
\text { (Seedling } \\
\text { high) } \\
(\mathrm{mm})\end{array}$ \\
\hline Adventif D1 & $100 \mathrm{a}$ & $5,8 \mathrm{ab}$ & $60 \mathrm{bc}$ & $2 b$ & $20 \mathrm{~b}$ & $2 \mathrm{a}$ & $6,5 \mathrm{~b}$ \\
\hline Adventif D2 & $100 \mathrm{a}$ & $5,2 \mathrm{ab}$ & $80 \mathrm{a}$ & $3 a b$ & $53 \mathrm{a}$ & $2 \mathrm{a}$ & $6,0 \mathrm{~b}$ \\
\hline Adventif D3 & $100 \mathrm{a}$ & $4,3 \mathrm{~b}$ & $70 \mathrm{ab}$ & $4 \mathrm{a}$ & $33 \mathrm{~b}$ & $2 \mathrm{a}$ & $7,0 \mathrm{ab}$ \\
\hline Adventif D4 & $100 \mathrm{a}$ & $4,1 \mathrm{~b}$ & $53 \mathrm{c}$ & $3 a b$ & $53 \mathrm{a}$ & $1 \mathrm{a}$ & $6,5 \mathrm{~b}$ \\
\hline Aksiler & $100 \mathrm{a}$ & $7,5 \mathrm{a}$ & $73 a b$ & $2 \mathrm{~b}$ & $23 \mathrm{~b}$ & $2 \mathrm{a}$ & $9,0 \mathrm{a}$ \\
\hline \multicolumn{8}{|c|}{$\begin{aligned} \text { Keterangan (Remaks): } & \text { Data sudah ditranformasi menggunakan metode arcsin } \sqrt{ } \% \text { (Data were transformea } \\
& \text { using arcsin } \sqrt{ } \% \text { method); Angka rerata yang diikuti oleh huruf yang sama pada } \\
& \text { kolom yang sama menunjukkan tidak berbeda nyata berdasarkan uji wilayah } \\
& \text { berganda duncan pada taraf } 5 \% \text {. (Mean followed by the same letter in the same } \\
& \text { column are not significantly different based on duncan multiple range test (DMRT) } \\
& \text { at } p=0.05 \text { ) }\end{aligned}$} \\
\hline
\end{tabular}

Bahan eksplan berupa potongan ruas pertama dan kedua dari tunas tembesu sudah memenuhi syarat faktor kedua. Posisi meletakkan eksplan tembesu dalam media juga sudah memenuhi persyaratan pada faktor kesatu dan ketiga. Tunas tersebut ditempatkan dengan posisi bagian bawah daun (adaksial) bersentuhan dengan media. Hal ini memungkinkan untuk unsur hara dan BAP masuk ke dalam jaringan daun melalui stomata secara difusi. Ketika eksplan ditanam dalam media, sitokinin yang ditambahkan ke dalam media sebanyak 1,5 ppm mulai bekerja dalam jaringan daun untuk mendorong sel membelah ke segala arah. Sitokinin (BAP) bekerja pada sel dari jaringan eksplan yang kontak dengan media, membentuk tunas adventif. BAP berperan dalam proses pembelahan dan pembesaran sel, ketika terjadi kontak antara eksplan daun dengan media, proses pembelahan sel di dalam jaringan daun terjadi dengan cepat. Pada minggu ke-4 mulai terlihat adanya titik putih dipermukaan daun tembesu yang kemudian berkembang menjadi tunas adventif seperti sel globular (Ardiansyah et al., 2014)

Konsentrasi zat pengatur tumbuh BAP (sitokinin) yang paling efektif membentuk tunas adventif adalah 1,5 ppm. Konsentrasi BAP sebesar 1,5 ppm yang ditambahkan dalam media mampu untuk menginduksi produksi hormon endogen seperti zeatin dalam jaringan daun, sehingga hormon endogen dan eksogen (BAP) bekerjasama membentuk tunas adventif tembesu dari daun. Siningia speciosa memerlukan hormon eksogen BA sebanyak $5 \mathrm{mg} / \mathrm{l}$ untuk menginduksi tunas dari batang dan daun (Lawalata, 2011). Penggunaan BAP secara tunggal pada eksplan daun tembesu menunjukkan efek kalus yang sangat kecil atau tidak terdapat kalus sama sekali. Penambahan BAP mendorong terbentuknya tunas adventif yang ditandai dengan terbentuknya butiran 
berwarna putih yang saling menempel dan kompak.

Konsentrasi BAP 1 dan 2 ppm tidak dapat menginduksi tunas adventif pada media dengan konsentrasi nitrogen sebanyak $60 \mathrm{mmol}$. Konsentrasi BAP 1 dan 2 ppm dapat menginduksi tunas adventif jika konsentrasi nitrogen dalam media ditingkatkan menjadi $80 \mathrm{mmol}$. Hal ini menunjukkan bahwa konsentrasi nitrogen di dalam media sangat berpengaruh terhadap efektivitas zat pengatur tumbuh. Pada manggis, media MS (total nitrogen $60 \mathrm{mmol}$ ) merupakan media dengan jumlah tunas adventif terbanyak dibandingkan dengan WPM (total nitrogen 14,8 mmol) dan B5 (total nitrogen 26,7 mmol) (Joni, Efendi, \& Roostika, 2015). Seperti yang telah diketahui, bahwa nitrogen merupakan unsur terbanyak penyusun sel tumbuhan. Sebagian besar unsur nitrogen ditransfer ke dalam eksplan dalam bentuk ion nitrat.

Berdasarkan hasil penelitian ini terbukti bahwa konsentrasi nitrogen pada semua perlakuan dalam media dapat menginduksi tunas adventif tembesu. Media dengan konsentrasi nitrogen sebanyak 70 dan $80 \mathrm{mmol}$ menghasilkan rata-rata jumlah total tunas adventif yang hampir sama jumlahnya, yaitu 48 tunas pada konsentrasi nitrogen $70 \mathrm{mmol}$ dan 45 tunas pada konsentrasi nitrogen 80 mmol. Akan tetapi jika dilihat kembali, media dengan konsentrasi nitrogen 80 mmol menghasilkan persentase tunas adventif yang lebih banyak (30\%), sehingga dimungkinkan untuk menghasilkan tunas adventif lebih banyak.

Untuk selanjutnya, total konsentrasi nitrogen yang digunakan untuk menginduksi tunas adventif tembesu adalah $80 \mathrm{mmol}$. Konsentrasi nitrogen dalam bentuk nitrat sebanyak tiga kali dari amonium digunakan untuk mendorong sel berdiferensiasi dan membelah. Hal ini berarti tunas adventif dari daun tembesu memerlukan konsentrasi nitrat lebih banyak untuk menginduksinya. Penelitian lain menggunakan konsentrasi nitrat yang mencapai tujuh kali dari ammonium digunakan untuk menginduksi tunas adventif dari daun Pyrus pyrifolia (Tang, Luo, \& Liu, 2008)

Konsentrasi nitrat yang ditingkatkan hingga $100 \mathrm{mmol}$ dapat menurunkan persentase tumbuh eksplan. Tidak hanya ammonium yang bersifat merugikan bagi tanaman (Sen \& Batra, 2011; Iranbakhsh, Ebadi, \& Zare, 2011), terbukti nitrat dalam jumlah banyak dalam media juga dapat merugikan bagi tanaman khususnya tembesu. Setiap perubahan konsentrasi nitrogen $\left(\mathrm{NO}_{3}{ }^{-}\right)$berpengaruh terhadap respon pembelahan sel, regenerasi eksplan, pertambahan biomassa dan abnormalitas pertumbuhan (Vinterhalter, Ninković, Zdravković-Korać, Subotić, \& Vinterhalter, 2007; Ivanova \& Van Staden, 2008; Rahman, Haider, Hossain, \& Islam, 2011). Dengan demikian, penggunaan media dengan knsentrasi nitrogen sebesar $80 \mathrm{mmol}$ merupakan konsentrasi terbaik untuk induksi tunas adventif.

Multiplikasi tunas secara in vitro sangat menentukan keberhasilan produksi bibit dengan cepat dan banyak. Semakin banyak tunas yang terbentuk akan mempengaruhi produksi bibit yang dihasilkan melalui kultur jaringan. Penggandaan tunas tembesu pada penelitian Ardiansyah (2015) menghasilkan jumlah tunas rata-rata sebesar dua belas tunas per eksplan (Tabel 6). Media yang digunakan adalah media dengan konsentrasi nitrogen sebanyak 80 mmol ditambah BAP 1,5 ppm. Dalam penelitian, ini tunas yang dihasilkan mencapai 35 tunas per eksplan, atau meningkat $192 \%$. Penggunaan media dengan konsentrasi BAP yang jauh lebih sedikit dari penelitian sebelumnya $(0,1$ ppm) terbukti lebih efisien dan ekonomis untuk menggandakan tunas tembesu. Multiplikasi tunas secara in vitro sangat menentukan keberhasilan produksi bibit 
dengan cepat dan banyak. Semakin banyak tunas yang terbentuk akan mempengaruhi produksi bibit yang dihasilkan melalui kultur jaringan.

Media multiplikasi yang digunakan mengandung $60 \mathrm{mmol}$ dari total nitrogen memiliki respon yang berbeda. Perbedaan antara total nitrogen $60 \mathrm{mmol}$ pada tahap induksi tunas (Tabel 4) dan multiplikasi tunas adalah dalam perbandingan antara $\mathrm{NH}_{4}{ }^{+}$dan $\mathrm{NO}_{3}{ }^{-}$. Dalam tahap induksi tunas, penelitian ini menggunakan perbandingan $\mathrm{NH}_{4}{ }^{+}$dan $\mathrm{NO}_{3}{ }^{-}$sebesar $1: 2$, sedangkan tahap multiplikasi perbandingan $\mathrm{NH}_{4}^{+}$dan $\mathrm{NO}_{3}^{-}$sebesar 1:3. Oleh karena itu, perbandingan $\mathrm{NH}_{4}^{+}$dan $\mathrm{NO}_{3}{ }^{-}$sangat mempengaruhi pembelahan sel. Konsentrasi total nitrogen di dalam media in vitro berkisar antara 14,58 sampai $60 \mathrm{mmol}$.

Total nitrogen sebanyak $60 \mathrm{mmol}$ merupakan konsentrasi tertinggi. Pada penelitian ini, total konsentrasi nitrogen yang digunakan untuk menginduksi tunas adventif tembesu adalah sebanyak 80 mmol. Induksi tunas adventif tembesu memerlukan konsentrasi nitrogen yang lebih banyak dengan perbandingan antara ammonium dan nitrat sebesar 1:3 (v:v). Hal ini menjelaskan bahwa tunas adventif dari daun tembesu memerlukan konsentrasi nitrat lebih banyak untuk menginduksinya. Induksi tunas adventif dari daun Pyrus pyrifolia memerlukan perbandingan ammonium nitrat mulai dari 1:2 sampai 1:7 (Tang et al., 2008).

Perbandingan tahap multiplikasi tunas tembesu yang dilakukan Ardiansyah, (2015) dengan hasil penelitian ini terdapat perbedaan yang cukup besar (Tabel 6). Perbandingan ammonium dan nitrat sebanyak 3:1 (v/v) pada konsentrasi nitrogen sebesar 60 mmol ditambah BAP sebanyak 0,1 ppm terbukti dapat menaikkan jumlah tunas mencapai 35 tunas per eksplan. Media multiplikasi yang digunakan lebih ekonomis dibandingkan dengan penelitian sebelumnya (Ardiansyah, 2015) yang memerlukan BAP sebanyak 15 kali lebih besar dari hasil penelitian ini. Konsentrasi nitrogen yang optimal pada tahap multplikasi tembesu adalah $60 \mathrm{mmol}$, sama dengan konsentrasi nitrogen optimal yang digunakan pada teknik kultur jaringan. Sebagian besar konsentrasi nitrogen dalam media kultur jaringan berada di bawah $60 \mathrm{mmol}$. Hal ini membuktikan bahwa tembesu masih mampu tumbuh pada media dengan konsentrasi nitrogen tinggi $(80 \mathrm{mmol})$.

Elongasi dan pengakaran pada penelitian ini hanya melihat perbedaan pertumbuhan antara tunas adventif beberapa klon dibandingkan dengan tunas aksiler. Hasil penelitian menyatakan bahwa tunas aksiler memiliki pertambahan panjang yang terbaik dibandingkan dengan keempat klon tunas adventif. Tembesu memliki sifat slow growing, hal tu juga terlihat pada proses regenerasi tunas tembesu pada teknik kultur jaringan, pertambahan panjang tunas tembesu tidak lebih dari $1 \mathrm{~cm}$ dalam waktu 4 minggu setelah ditanam. Sifat tersebut juga sama dengan semai generatif yang disapih di rumah kaca. Pertambahan tinggi bibit tembesu di persemaian sekitar 1-3 cm per bulan, dengan syarat bibit dalam kondisi baik dan diberi pupuk(Agus Sofyan \& Lukman, 2014).

Pengakaran tembesu secara in vitro tidak menggunakan penambahan hormon auksin. Auksin dalam eksplan tembesu sudah cukup untuk mendorong terbentuknya akar pada media arang dengan unsur hara yang diturunkan setengahnya. Arang dalam media menyerap semua unsur bahan kimia yang menumpuk dalam jaringan eksplan, sehingga eksplan dapat tumbuh normal. Pertumbuhan normal tunas tembesu dalam media arang adalah batangnya tampak lebih kokoh, berwarna hijau gelap, daun berwarna hijau, luasnya lebih lebar dibandingkan dengan media multiplikasi dan media induksi. 
Perbedaan morfologi antara tunas adventif (klon 1, 2, 3, dan 4) dan tunas aksiler juga tidak jelas terlihat (Lampiran 2). Perbedaan terlihat ketika tunas adventif dan tunas aksiler dipindahkan dari lingkungan aseptik ke dalam lingkungan autotrof. Tunas aksiler memiliki pertumbuhan lebih rendah dari tunas adventif dilihat berdasarkan pengamatan pertumbuhan pada minggu ke-5 setelah tanam.

Aklimatisasi merupakan tahap penyesuaian planlet di lingkungan autotrof. Proses adaptasi dimulai dengan penyesuaian planlet dari ruang ber-AC ke suhu ruangan. Planlet yang ditanam dalam wadah aklimatisasi ditutup rapat menggunakan plastik untuk menghindari terjadinya penguapan yang berlebih pada planlet. Bibit hasil kultur jaringan memiliki kelemahan, antara lain mekanisme buka tutup stomata yang lemah sehingga mudah terdehidrasi, tidak tahan terhadap intensitas sinar yang tinggi, dan terbiasa dengan nutrisi yang selalu tersedia. Oleh karena itu, tahap aklimatisasi merupakan tahapan yang sangat rawan untuk menghasilkan bibit hasil kultur jaringan. Setelah 5 minggu, mulai terlihat proses adaptasi, planlet yang tidak dapat bertahan mulai mengalami kematian. Kematian planlet dimulai pada bagian batang yang dekat dengan media berubah warnanya menjadi coklat. Perubahan tersebut terjadi sampai ke bagian daun dan akhirnya planlet mati. Kontaminasi pada planlet dan media tidak terjadi. Hal ini menandakan bahwa proses pencucian planlet sudah benar, begitu juga dengan proses sterilisasi media.

Planlet yang dapat bertahan hidup setelah minggu ke-5 mengalami penambahan jumlah daun dan tinggi bibit. Hasil pengamatan pertumbuhan bibit tembesu hasil kultur jaringan belum dapat tumbuh dengan baik sampai pengamatan 5 minggu. Jumlah bibit yang dihasilkan setelah minggu kedelapan sangat sedikit
(Lampiran 1). Pengamatan pertumbuhan bibit tembesu asal tunas aksiler dengan tunas adventif terlihat perbedaannya. Tunas aksiler tumbuh lebih lambat dari tunas adventif (klon 4). Tinggi tunas adventif klon 4 mencapai $4 \mathrm{~cm}$ sedangkan tinggi bibit aksiler hanya mencapai $2 \mathrm{~cm}$. Pengamatan morfologi antara bibit asal tunas aksiler dengan tunas adventif belum terlihat secara nyata perbedaannya.

\section{KESIMPULAN DAN SARAN}

\section{A. Kesimpulan}

Modifikasi media tumbuh MS yang tepat untuk mendapatkan tunas adventif dari daun tembesu adalah media MS dengan konsentrasi nitrogen sebanyak 80 mmol ditambahkan dengan BAP sebanyak 1,5 ppm. Konsentrasi nitrogen yang terlalu tinggi (90 dan $100 \mathrm{mmol}$ ) dalam media mengakibatkan kematian bagi eksplan. Multiplikasi tunas adventif tembesu dapat dilakukan dengan menggunakan modifikasi media MS dengan konsentrasi nitrogen $60 \mathrm{mmol}$ (perbandingan $\mathrm{NO}_{3}{ }^{-}: \mathrm{NH}_{4}{ }^{+}=3: 1,(\mathrm{v}: \mathrm{v})$ ) ditambah BAP 0,1 ppm.

Tunas adventif (klon 2) merupakan asal tunas yang memiliki pertumbuhan paling baik pada tahap elongasi, dan pengakaran. Persentase tumbuh pada tahap aklimatisasi tertinggi berasal dari tunas adventif klon 4.

\section{B. Saran}

Multipikasi tunas adventif tembesu dapat menggunakan BAP dengan konsentrasi rendah $(0,1 \mathrm{ppm})$. Perlu pengujian lebih lanjut tentang stabilitas klon hasil induksi tunas adventif pada perbanyakan in vitro serta pengujian pertumbuhan dari empat klon yang diperoleh. 


\section{UCAPAN TERIMAKASIH}

Penelitian ini dibiayai dari DIPA APBN Pusat Pendidikan dan Pelatihan Kementrian Lingkungan Hidup dan Kehutanan tahun 2015. Penulis mengucapkan terimakasih atas dukungan Balai Penelitian dan Pengembangan Teknologi Perbenihan Tanaman Hutan dan Rumpin Seed Source and Nursery Center (Direktorat Perbenihan Tanaman HutanKIFC). Penulis juga mengucapkan terimakasih kepada Yuli Fitriyani, Cecep Subarnas, Cecep Dulhalim dan Abay yang telah membantu penelitian ini.

\section{DAFTAR PUSTAKA}

Ardiansyah, R. (2015). Mikropropagasi Tembesu ( Fagraea fragrans $R O X B)$. Institut Pertanian Bogor.

Ardiansyah, R., Supriyanto, Wulandari, A. S., Subandy, B., \& Fitriani, Y. (2014). Teknik Sterilisasi Eksplan dan Induksi Tunas Dalam Mikropropagasi Tembesu ( Fagraea fragrans ROXB ), 5(3), 167-173.

Iranbakhsh, A., Ebadi, M., \& Zare, Z. (2011). Effects of Nitrogen and Potasium on in vitro Microtuberization of Potato (Solanum tuberosum L. var Agria). Australian Journal of Basic and Applied Sciences, 5(12), 442-448.

Ivanova, M., \& Van Staden, J. (2008). Effect of ammonium ions and cytokinins on hyperhydricity and multiplication rate of in vitro regenerated shoots of Aloe polyphylla. Plant Cell, Tissue and Organ Culture, 92(2), 227-231. https://doi.org/10.1007/s11240-0079311-7

Joni, Y., Efendi, D., \& Roostika, I. (2015). induksi perakaran manggis (Garcinic mangostana L) secara in vitro dan ex vitro. J.Hort., 2(25), 97-105.
Jonville, M. C., Capel, M., Frédérich, M., Angenot, L., Dive, G., Faure, R., ... Ollivier, E. (2008). Fagraldehyde, a secoiridoid isolated from Fagraea fragrans. Journal of Natural Products, 71(12), 2038-2040. https://doi.org/10.1021/np800291d

Lawalata, I. J. (2011). Pemberian Beberapa Kombinasi ZPT Terhadap Regenerasi Tanaman Gloxinia ( Siningia speciosa ) dari Eksplan Batang dan Daun Secara In Vitro. J.Exp.Life Sci, 1(2), 83-87.

Rahman, M. H., Haider, S. A., Hossain, M., \& Islam, R. (2011). Effect of potassium and ammonium nitrate medium on in vitro growth response of potato (Solanum tuberosun L.). J.Biosciences, 2(1), 54-61.

Sen, A., \& Batra, A. (2011). Crucial Role of Nitrogen In -Vitro Regeneration of Phyllanthus amarus Schun and Thonn. International Journal of Pharmaceutical Sciences and Research, 2(8), 2146-2151.

Sianturi, R. U. D. (2016). Induksi tunas adventif dari daun tembesu (Fagraea fragrans ROXB). Institut Pertanian Bogor.

Sofyan, A., \& Lukman, A. H. (2014). Tembesu kayu raja andalan sumatra. In H. S. Nurohmah, C. Akhmad, \& N. Mindawati (Eds.) (pp. 41-55). Forda Press.

Sofyan, A., Lukman, A., Junaidah, \& Nasrun. (2013). Peningkatan riap pertumbuhan tanaman tembesu melalui beberapa perlakuan silvikultur. In Prosiding Seminar Hasil Penelitian Balai Penelitian Kehutanan Integrasi IPTEK dalam Kebijakan dan Pengelolaan Hutan Tanaman di Sumatra Bagian Selatan (pp. 53-59). Palembang: Pusat Penelitian dan Pengembangan Peningkatan Produktivitas Hutan. 
Badan Penelitian dan Pengembangan Kehutanan. Kementrian Kehutanan.

Tang, H., Luo, Y., \& Liu, C. (2008). Plant regeneration from in vitro leaves of four commercial Pyrus species. Plant, Soil and Environment, 54(4), 140-148.

Vinterhalter, B., Ninković, S., Zdravković-Korać, S., Subotić, A.,
\& Vinterhalter, D. (2007). Effect of nitrogen salts on the growth of Ceratonia siliqua L. Shoot cultures. Archives of Biological Sciences, 59(3), 217-222. https://doi.org/10.2298/ABS070321 $7 \mathrm{~V}$ 


\section{Regenerasi Tunas Adventif Dari Eksplan Daun Tembesu (Fagraea fragrans Roxb.) Melalui Teknik Kultur Jaringan}

Ratna Uli Damayanti S, Supriyanto, Arum Sekar Wulandari dan Benny Subandy

Lampiran (Appendix) 1. Hasil pengamatan persentase tumbuh bibit tembesu hasil kultur jaringan (minggu ke-8) (The result of seedling survival from tissue culture (8 week)

\begin{tabular}{clc}
\hline No & \multicolumn{1}{c}{$\begin{array}{c}\text { Perlakuan } \\
\text { (Treatment) }\end{array}$} & $\begin{array}{c}\text { Persentase } \\
\text { tumbuh bibit } \\
\text { (Survival of } \\
\text { seedling) }(\%)\end{array}$ \\
\hline 1 & Klon 1 & 2 \\
2 & Klon 2 & 0 \\
3 & Klon 3 & 5 \\
4 & Klon 4 & 10 \\
5 & Aksiler & 6 \\
\hline
\end{tabular}

Lampiran (Appendix) 2. Planlet tembesu (A) tunas adventif klon 1, (B) tunas adventif klon 2, (C) tunas adventif klon 3, (D) tunas adventif klon 4 (E) tunas aksiler (Termbesu eksplan (A) adventitious clon 1 (B) adventitious clon 2 (C) adventitious clon 3 (D) adventitious clon 4 (E) axillary shoot)
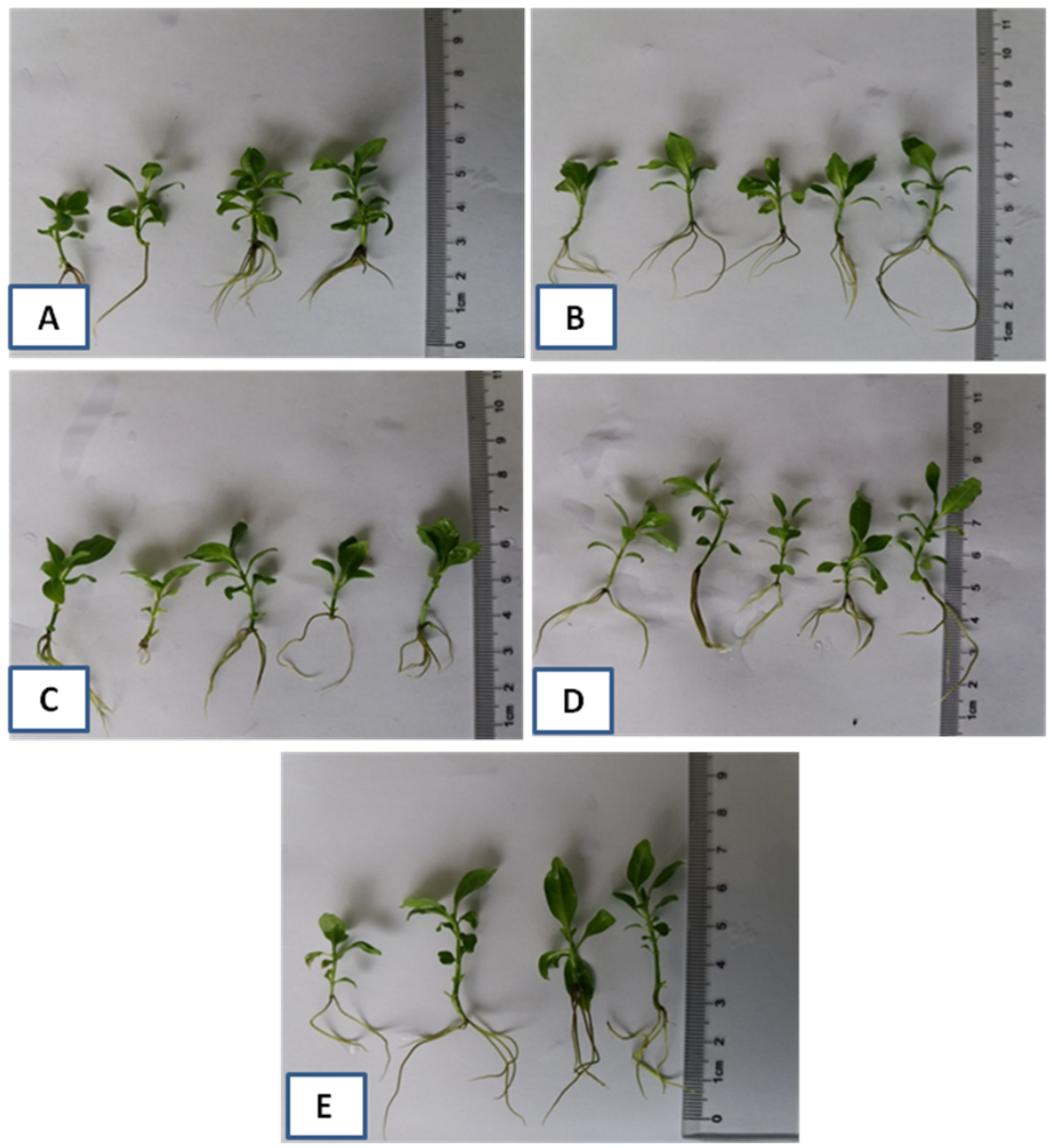